\title{
PENERAPAN STRUKTUR PNEUMATIK BERUPA ATAP PANGGUNG TIUP DENGAN ENERGI FOTOVOLTAIK
}

\author{
Hery Budiyanto $^{1 *}$, Erna Winansih ${ }^{2}$, Aries Budi Setiawan ${ }^{3}$ dan Muhammad Iqbal ${ }^{4}$ \\ Prodi Arsitektur, Universitas Merdeka Malang ${ }^{1}$ \\ Prodi Arsitektur, Universitas Merdeka Malang² \\ Prodi Teknik Elektro, Universitas Merdeka Malang 3 \\ S2 Magister Arsitektur, Universitas Merdeka Malang ${ }^{4}$ \\ Alamat Korespondensi: Jl. Puncak Jaya 28 Malang \\ *hery.budiyanto@unmer.ac.id
}

\begin{abstract}
ABSTRAK
Penerapan struktur pneumatik berupa atap panggung struktur tiup dengan energi fotovoltaik ini merupakan hasil Penelitian Terapan Unggulan Perguruan Tinggi. Fasilitas ini terbuat dari bahan kain Terpaulin berlapis PVC yang dapat dibangun, dibongkar serta dipindahkan ke lokasi lain secara mudah, aman, cepat dan ringan dengan sumber energi mandiri (sistem energi surya fotovoltaik). Tujuan penelitian adalah mengembangkan fasilitas atap panggung sebagai sarana pameran produk UKM yang memenuhi aspek estetika, kekuatan, kecepatan, efektifitas, kenyamanan dan hemat energi sehingga dapat mendorong pengembangan UKM ekonomi kreatif. Metode Penelitian menggunakan Metode Eksperimen dan Action Research, diawali dengan pengembangan rancang bangun, pembuatan dan pengujian atap panggung pneumatik tiup energi mandiri, meliputi: (1) uji kecepatan pembuatan, pengangkutan, perakitan, pemasangan, pembongkaran atap struktur pneumatik tiup dan modul energi surya, (2) uji kekuatan bahan Air Inflated (3) uji kenyamanan termal dibawah atap panggung tiup, (4) uji efektivitas penggunaan energi surya fotovoltaik untuk menggerakkan blower peniup atap panggung tiup. Pengujian bahan dilakukan di Lab Tekstil Universitas Islam Indonesia (UII), Lab Sains Universitas Merdeka Malang serta Uji Lapangan di Kota dan Kabupaten Malang, terbukti memberikan hasil yang handal dan memuaskan, meliputi: a) kecepatan instalasi pemasangan dan pembongkaran (atap panggung 6 menit, instalasi panel surya 15 menit), b) tekanan udara yang dibutuhkan hanya 0,9 psi untuk mendirikan atap panggung tiup, c) kekuatan tarik bahan tarpaulin PVC mencapai 55,619 kg/cm, d) 4 buah panel surya masing-masing berkapasitas 100 wp dengan penyimpan energi berupa sebuah baterei $100 \mathrm{AH} 12 \mathrm{~V}$ dan inverter $1000 \mathrm{WH}$ dalam kondisi cerah menghasilkan minimum 11,6 Amp, 18,8 V dapat mencukupi kebutuhan energi untuk menggerakkan blower peniup atap panggung tiup dan portable sound system, serta f) kenyamanan dibawah atap tiup suhu maksimum 35 derajad Celsius. Atap panggung tiup energi mandiri yang praktis dan cepat bangun ini diharapkan menjadi prototip fasilitas panggung untuk Pameran UKM dalam skala nasional.
\end{abstract}

Kata kunci: atap panggung, tiup, fotovoltaik 


\begin{abstract}
The application of pneumatic structures in the form of a roofcover with inflatable photovoltaic energy is the result of Higher Education Applied Research. This facility is made of Terpaulin PVC coated fabric which can be built, dismantled and moved to another location easily, safely, quickly and lightly with a standalone energy source (photovoltaic solar energy system). The aim of the research is to develop a stage roofcover facility as a means of exhibiting SME products that meets the aesthetic, strength, speed, effectiveness, comfort and energy saving aspects so as to encourage the development of creative economy SMEs. The research method uses the Experimental and Action Research Method, beginning with the development of the design, manufacture and testing of the independent energy pneumatic inflatable stage roofcover, including: (1) speed test for the manufacture, transportation, assembly, installation, dismantling of the roof of pneumatic inflatable structures and solar energy modules, (2) Air Inflated material strength test (3) thermal comfort test under the inflatable stage roof, (4) test the effectiveness of the use of photovoltaic solar energy to drive the blowers of the inflatable stage roof. Material testing conducted at the Textile Laboratory of the Islamic University of Indonesia (UII), the University of Malang Science Lab and Field Tests in the City and Regency of Malang, has proven to provide reliable and satisfying results, including: a) the speed of installation and dismantling installation (6 minute stage roofcover, solar panel installation 15 minutes), b) the air pressure needed is only 0.9 psi to erect an inflatable stage roofcover, c) the tensile strength of PVC tarpaulin material reaches $55,619 \mathrm{~kg} / \mathrm{cm}, \mathrm{d}) 4$ solar panels each with a capacity of 100 wp with energy storage in the form of a $100 \mathrm{AH} 12 \mathrm{~V}$ battery and a $1000 \mathrm{WH}$ inverter in sunny conditions produces a minimum of $11.6 \mathrm{Amp}, 18.8 \mathrm{~V}$ can meet the energy requirements for moving the blowers on the inflatable stage roof blower and portable sound system, and $f$ ) comfort under the inflatable roof a maximum temperature of 35 degrees Celsius. The practical and quick-wake stage of the independent energy inflatable stage is expected to be a prototype stage facility for the SME Exhibition on a national scale.
\end{abstract}

Keyword: stage roof, inflatable, photovoltaic

\section{PENDAHULUAN}

Usaha Kecil dan Menengah (UKM) memiliki peran sangat penting dalam pembangunan ekonomi nasional. Hal tersebut dikarenakan selain berperan terhadap pertumbuhan dan penyerapan tenaga kerja, juga berperan dalamdalam pendistribusian hasil-hasil pembangunan. Perusahaan kecil dapat menyerap 51\% tenaga nasional (Manurung, 2006). Di Indonesia, secara kuantitas UKM juga unggul, hal ini didasarkan pada fakta bahwa sebagian besar usaha di Indonesia yaitu lebih dari $99 \%$ berbentuk usaha skala kecil menengah. Bahkan UKM memberikan kontribusi yang sangat signifikan terutama ketika krisis yang dialami pada periode 1998-2000. Dalam krisis ekonomi, dimana usaha-usaha berskala besar terlihat mengalami stagnansi bahkan berhenti aktivitasnya, sektor UKM menunjukkan potensi untuk terus bertahan dan 
berkembang sehingga selalu diperlukan program pengembangan UKM industri kreatif di Indonesia.

Dalam hal pelaku kegiatan industri kreatif, Kota Malang memiliki 77.778 UKM dan 141.906 pekerja di berbagai bidang usaha, salah satunya adalah kerajinan. UKM Kota Malang dikenal memiliki produk yang bagus dan berkualitas (Rofieq, at.al. 2018), Untuk meningkatkan pemasaran, Pameran produk UKM merupakan salah satu cara pemasaran yang efektif bagi UKM ekonomi kreatif yang perlu didukung oleh peran Perguruan Tinggi (Budiyanto, Hery \& Rofieq, Mochammad. 2018). Salah satu bagian terpenting dalam pameran produk UKM adalah panggung hiburan yang menjadi daya tarik bagi pengunjung untuk datang dan berada di area pameran. Penelitian ini berfokus pada perancangan dan pembuatan atap panggung struktur tiup energi mandiri sebagai sarana pameran produk UKM, menggunakan bahan kain tarpaulin yang dilapis PVC sehingga lebih ringan dan ringkas serta cepat dalam memasang dan membongkarnya (Budiyanto, at.al. 2018).

Terdapat 4 aspek utama yang menjadi masalah dalam penelitian ini, yaitu: 1) Perancangan dan pembuatan atap panggung tiup energi mandiri untuk pameran UKM; 2) Kecepatan dan efektivitas dalam proses pengangkutan, perakitan, pemasangan serta pembongkaran bangunan panggung portable dan atap panggung tiup energi mandiri; 3) Tingkat kenyamanan termal dalam bangunan panggung portable dan atap penggung tiup energi mandiri; 4) Efisiensi energi surya fotovoltaik dalam menyediakan energi untuk atap penggung tiup.
Pelaksanaan penelitian dilakukan di Laboratorium bahan dan di lapangan. Pengujian bahan membran berupa uji kekuatan kain tarpaulin PVC kain pararsit dilaksanakan di Laboratoriun Tekstil Universitas Islam Indonesia (UII) Yogyakarta, sedangkan pengujian penggunaan atap panggung tiup dilaksanakan pada beberapa tempat, yaitu: 1) Parade Handicraft di Halaman Skodam Kota Malang (Juli 2019); 2) Panggung Penutupan KKN Mahasiswa dan Panggung Gerakan Membangun Desa di Kampung Bunga Grangsil, Desa Jambangan, Dampit, Kab. Malang (Agustus 2019); 3) Panggung Gerakan Generasi Emas Anti Narkoba di ITN Kota Malang (September 2019).

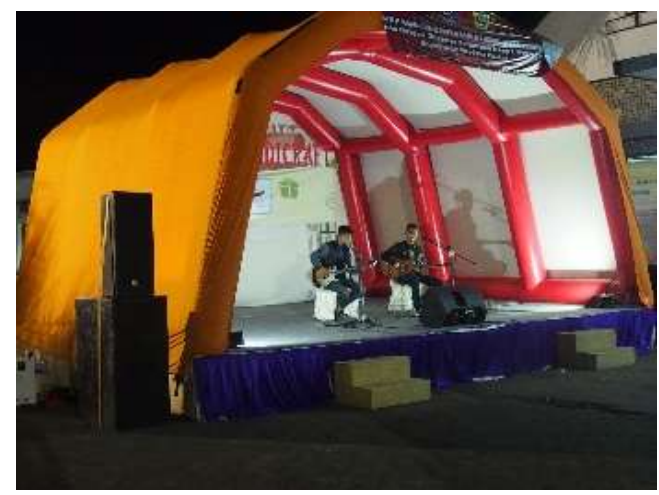

Gambar 1: Parade Handicraft, Juli 2019 


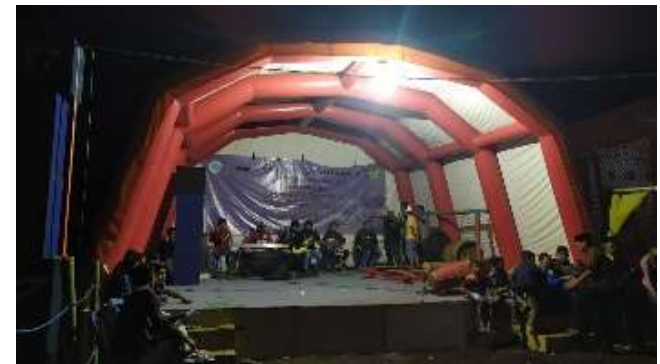

Gambar 2: Penutupan KKN, Agustus 2019

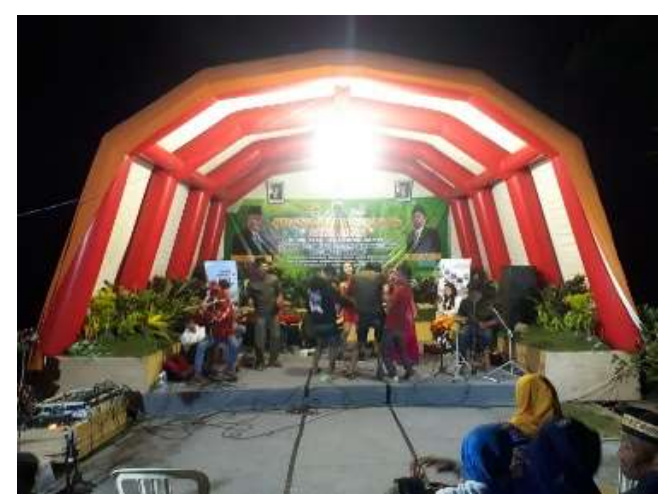

Gambar 3: Gerakan Membangun Desa, Agustus 2019

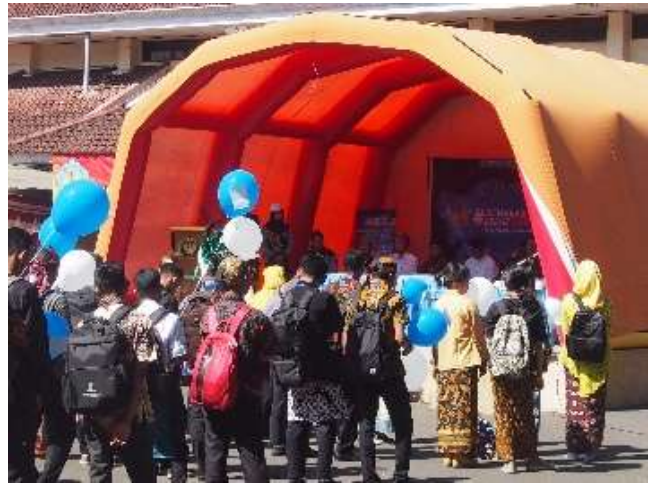

Gambar 4: Gerakan Generasi Emas Anti Narkoba ITN, September 2019

\section{KAJIAN LITERATUR}

\section{Struktur Pneumatik Tiup}

Struktur membran pneumatik merupakan salah satu sistem struktur soft shell, dimana struktur dapat berdiri akibat perbedaan tekanan udara di dalam struktur pneumatik dengan tekanan udara di luar struktur (Sukawi, 2011). Struktur pneumatik dibagi menjadi 2 kelompok besar yaitu air supported structure dan air inflated structure (Schodek, 1980).a) air supported structure yang disebut sebagai single membrane structure karena hanya membutuhkan satu lapis membran dan membutuhkan tekanan udara rendah (sekitar 2-20 pon per feet diatas tekanan atmosfir). b) air inflated structure (gambar 5) disebut juga double membrane structure. 

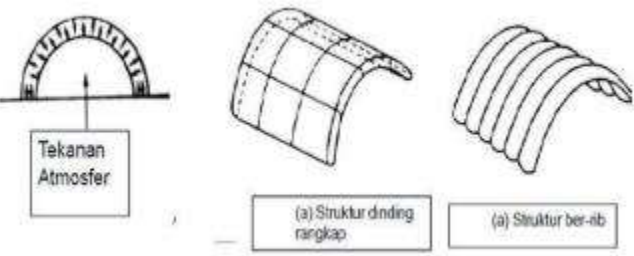

Gambar 5: Struktur Pneumatik yang Digelembungkan Udara (Air Inflated) (Sumber: Schodek, 1980)

Struktur berbahan kain yang digelembungkan udara termasuk dalam kategori struktur yang ditegangkan dan mempunyai kelebihan yang unik dalam penggunaannya dibandingkan struktur tradisional. Keunggulan ini meliputi desain ringan, cepat dan mudah dipasang, cepat diangkut dan volume pengepakan kecil. Sebagian besar penelitian dan pengembangan struktur yang digelembungkan dilakukan pada fungsi ruang angkasa, militer, komersial, kelautan dan rekreasi, Contohnya: kapal udara, balon cuaca, antena tiup dan radom, tempat penampungan sementara, perahu karet, jembatan darurat, dan kantong udara otomotif (Avallone, 2006).

\section{Pembangkit Listrik Fotovoltaik}

Komponen utama suatu Sistem Energi Surya Fotovoltaik adalah sel fotovoltaik yang mengubah penyinaran/radiasi matahari menjadi listrik secara langsung (direct conversion) yang ditangkap oleh Solar Array, diperlukan Balance of System (BOS) meliputi charge controller dan inverter, unit penyimpan energi (battery) dan peralatan penunjang lain (Gambar 6). Sistem energi ini akan menunjang kebutuhan listrik blower sebagai sumber udara pada struktur pneumatik air inflated atap panggung.

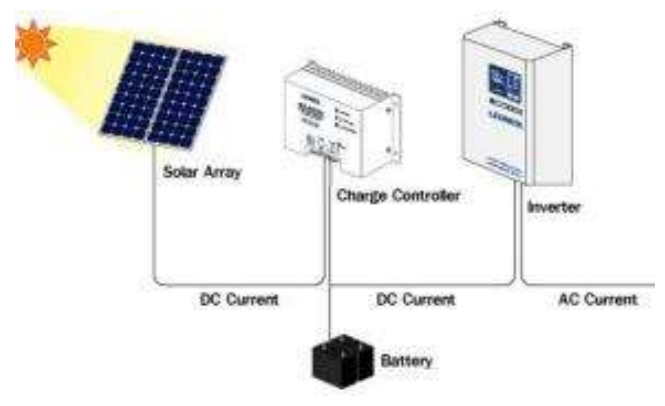

Gambar 6: Sistem Energi Surya Fotovoltaik Sumber: Widayana, 2012

\section{METODE}

Penelitian ini menggunakan metode eksperimental dan action research berupa pembuatan prototip, melakukan uji coba Laboratorium dan uji coba Lapangan terhadap berbagai variabel (Chassagnoux, Alain, et.al. 2002.). Dalam penelitian ini dilakukan berbagai uji yaitu: a) bahan membran tiup, c) pengujian tekanan dalam tabung membrane tiup, d) uji kenyamanan termal dibawah atap panggung tiup, e). pengujian bahan dan $\mathrm{f}$ ) efektivitas sistem catu daya fotovoltaik tenaga surya. Variabel dalam penelitian ini adalah: a) Kecepatan proses pembuatan, perakitan, pemasangan, pembongkaran, b) Efisiensi Sistem dan Komponen Struktur, c) Tekanan udara di dalam tabung membran tiup, d) Kondisi termal bangunan, e) Kekuatan bahan membran, f) Energi surya fotovoltaik. 
Uji kekuatan Tarik dan mulur serta uji daya tembus air dilakuan di Lab. Tekstil UII Yogyakarta menggunakan alat tenso lab. Alat ini dapat mengetahui kekuatan Tarik maksimal dari kain tarpaulin-PVC dan kain parasit. Selain itu dilakukan uji daya tembus air dengan alat $W$ ater Permeability.

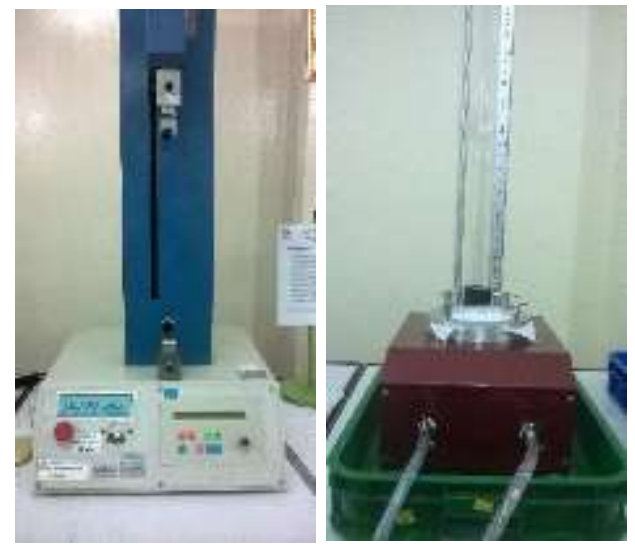

Gambar 7: Alat uji kekuatan Tarik dan Daya Tembus Air

\section{HASIL DAN PEMBAHASAN}

Desain Atap Panggung Struktur Pneumatik Tiup

\section{Energi Surya}

Gambar berikut memperlihatkan desain atap panggung tiup dengan energi mandiri fotovoltaik.

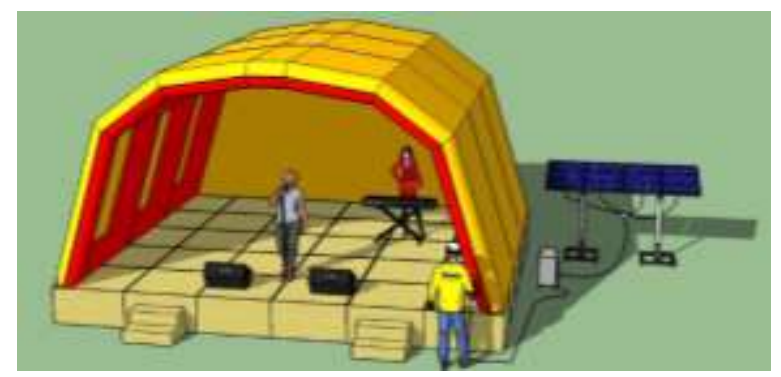

Gambar 8: Desain Atap Panggung Struktur Pneumatik Tium Energi Surya

\section{Pembuatan panggung portable}

Panggung dibuat dari bahan multipleks $18 \mathrm{~mm}$, dirancang untuk bisa dibongkarpasang secara portable. Terdiri dari 30 modul, masing-masing berukuran $120 \times 120 \times 60 \mathrm{~cm}$ 

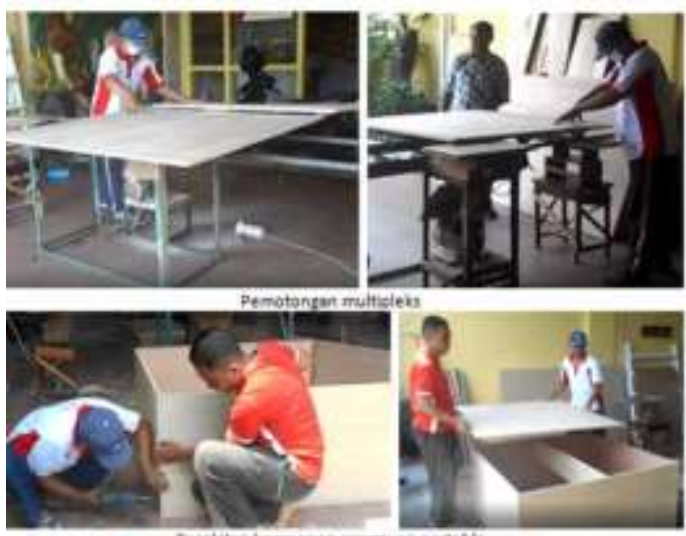

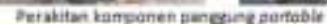

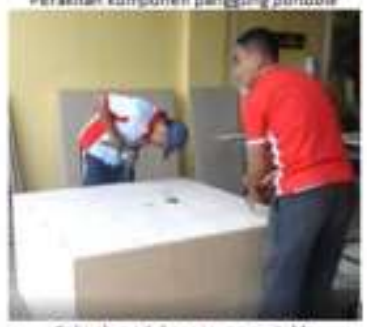

Sebiah nodul paniturs potabite

Gambar 9: Pembuatan Panggung Portable (2 minggu)

\section{Perakitan panggung portable}

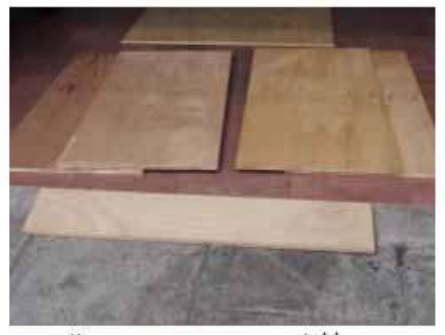

Komponen panggung portable

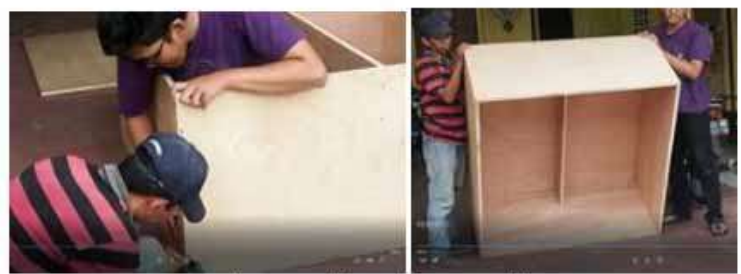

Perakitan 1 modul panggung portable
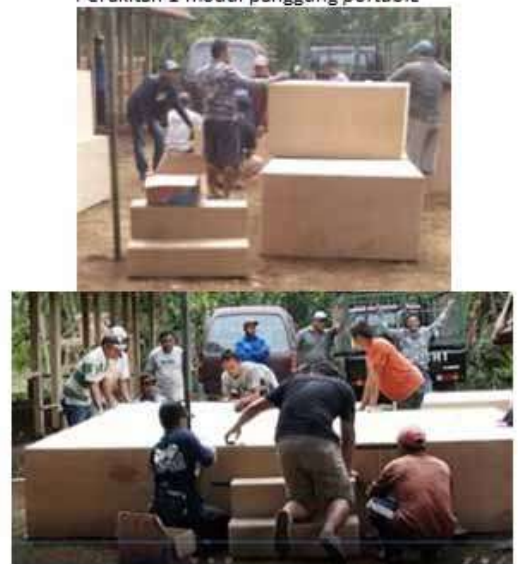

Pemasangan panggung portable

Gambar 10: Perakitan Panggung Portable (50 menit) 


\section{Pembuatan dan perakitan atap panggung tiup}

Urutan pembuatan adalah sebagai berikut: a) penyiapan bahan kain tarpaulin lapis PVC, b) pemotongan, c, pengelaman, d) perakitan tabung tiup, e) pemasangan penutup atap.

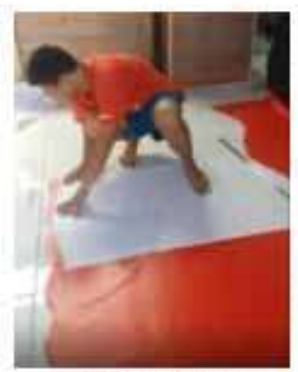

Pemotongan

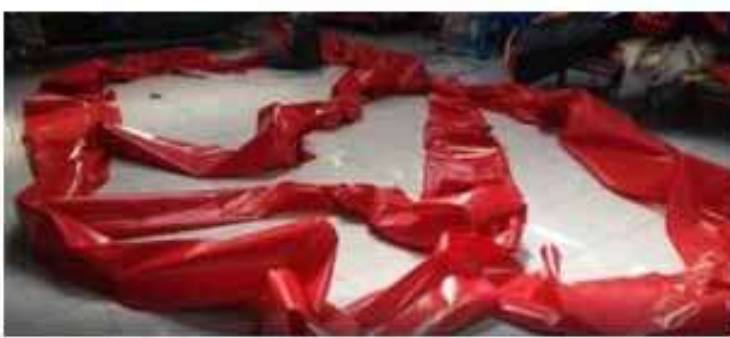

Komponen tabung inflatable

Gambar 11: Pembuatan Prototip Atap Panggung Tiup (2 minggu)

\section{Pemasangan atap panggung tiup}
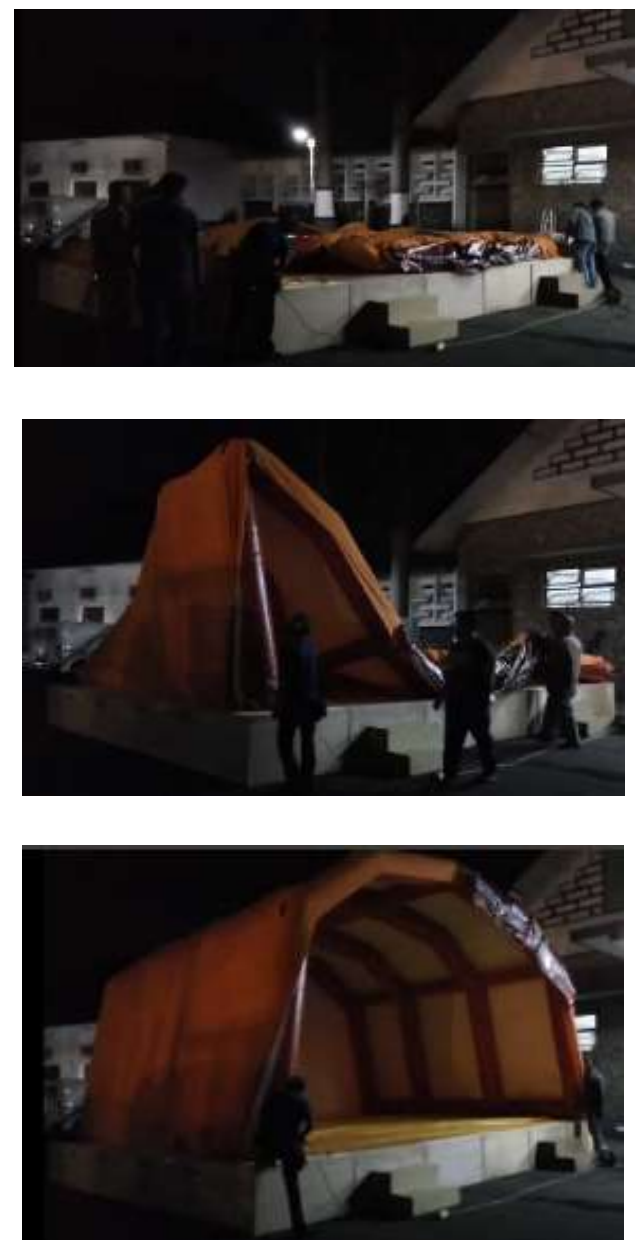

Gambar 12: Pemasangan Prototip Atap Panggung Tiup (6 menit) 
Pemasangan Portable Bracket dan Panel Solar Energi Fotovoltaik

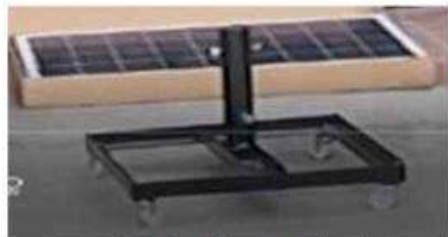

Penyiapan komponen bracket

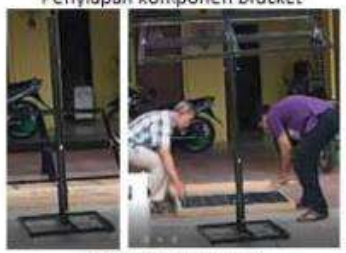

Pemasangan bracket

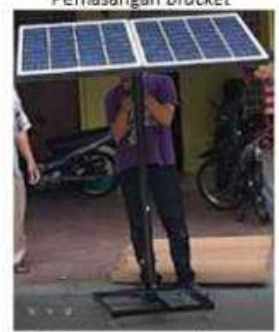

Pemasangan panel surya

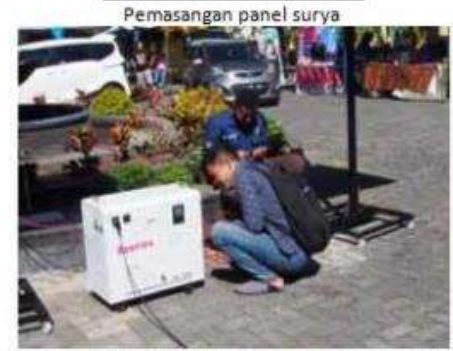

Pemasangan jaringan kabel panel surya menuju controller

Gambar 13: Pemasangan Portable Bracket dan Panel Solar Energi Fotovoltaik (20 menitt)
Pemanfaatan Prototip Panggung Portable dan Atap Panggung Tiup

Panggung Portable dan Atap Panggung Tiup telah di rancang dan dimanfaatkan di kegiatan-kegiatan: Parade Handicraft (Juli 2019 - Gambar 1); Penutupan KKN Mahasiswa (Agustus 2019 - Gambar 2; Gerakan Membangun Desa (Agustus 2019 - Gambar 3); Gerakan Anti Narkoba ITN (September 2019 Gambar 4).

Uji tekanan udara di dalam tabung membrane tiup

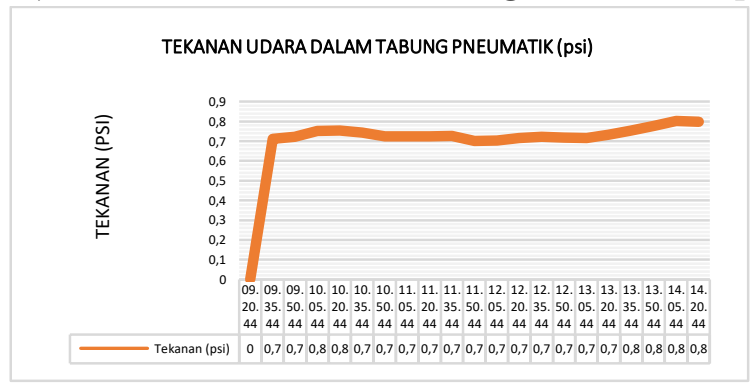

Gambar 14: Grafik Tekanan Dalam Tabung Membran Atap Panggung Tiup

Tekanan udara minimum yang dibutuhkan untuk tegaknya tabung membran tiup adalah 0,7 psi, tekanan ini dicapai dalam waktu 6 menit dari awal penggelembungan.

Kondisi termal dalam dan luar atap panggung tiup 


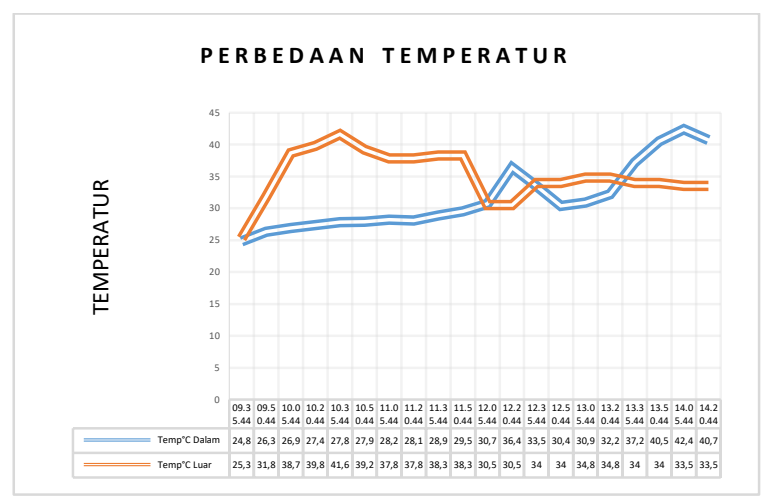

Gambar 15: Grafik Kondisi Termal Dalam dan Luar Atap Panggung Tiup

Pada pagi 09.05 Pagi hingga jam 12.05 pagi suhu udara di dalam panggung lebih rendah dari luar panggung. Terdapat perbedaan suhu udara di dalam dan luar panggung antara $-4,9^{\circ} \mathrm{C}$ hingga $3,8^{\circ} \mathrm{C}$.

\section{Kekuatan dan kemuluran membran tabung atap panggung tiup}

Pengujian kekuatan membrane tabung atap panggung tiup dilakukan di Lab. Tekstil Universitas Islam Indonesia Yogyakarta dengan hasil sebagai berikut:

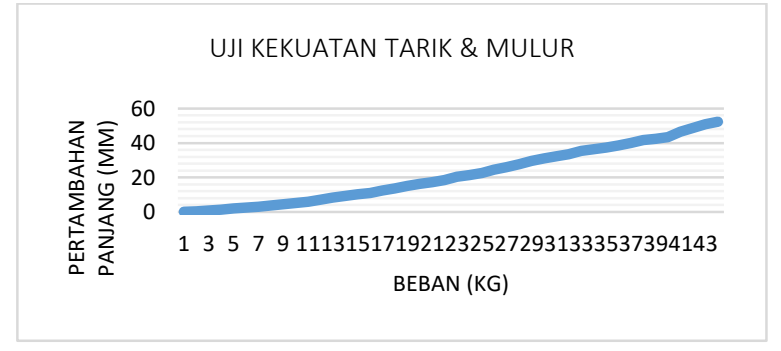

Gambar 16: Grafik Uji Beban terhadap Bahan Kain Tarpaulin Lapis PVC

Kekuatan maksimum membran kain tarpaulin berlapis pvc tebal $0,5 \mathrm{~mm}$ dicapai pada beban 55,619 $\mathrm{kg}$, nilai kemuluran 21,453\% untuk lebar permukaan $1 \mathrm{~cm}$.

\section{Pengujian energi surya fotovoltaik}

Hasil pengujian terhadap panel surya masing-masing 100 wp adalah sebagai berikut:

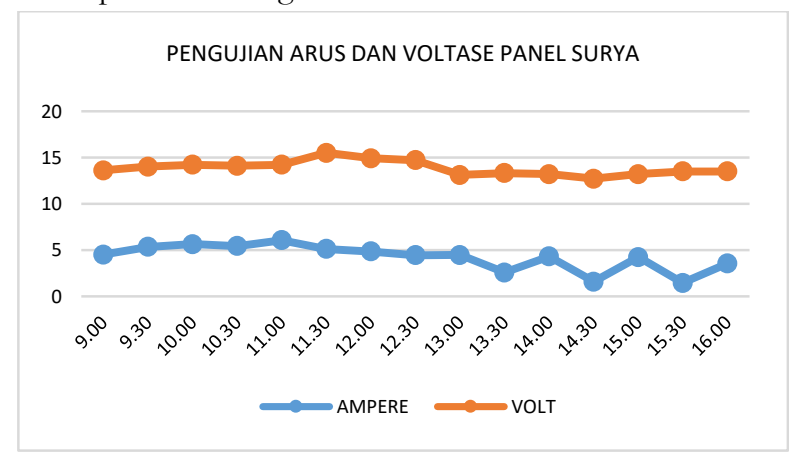

Gambar 17: Grafik Arus dan Voltase Panel Surya 
Pada cuaca cerah, 1 buah panel surya $100 \mathrm{WP}$ dapat menghasilkan rata-rata 4,2 Amper 13,8 Volt, sedangkan ketika cuaca mendung arus menurun hingga 1,4 Amper 6,07 Volt. Energi listrik yang tersimpan di dalam batterei sudah dapat digunakan untuk menggerakkan blower dengan daya 550 Watt tegangan 220 Volt, blower ini bekerja untuk meniup atap panggung tiup selama 6 menit dan mengosongkan angin selama 12 menit.

\section{KESIMPULAN DAN SARAN}

\section{Kesimpulan}

Panggung portable dan atap panggung tiup energi mandiri sangat sesuai untuk kebutuhan pameran pemasaran produk UKM, hal ini disebabkan kecepatan, kemudahan dan kenyamanan bangunan struktur tersebut. Terbukti dalam Uji Laboratorium dan Uji Lapangan didapatkan hasil yang handal meliputi kuat uji tarik bahan atap panggung tarpaulin lapis pvc mampu menahan hingga $55,619 \mathrm{~kg} / \mathrm{cm}^{2}$, instalasi panggung portable 50 menit pemasangan atap tiup 6 menit dan pembongkaran 10 menit serta mampu menurunkan suhu rata-rata dibawah $\operatorname{atap} 2,2^{\circ} \mathrm{C}$.

Kebutuhan energi listrik untuk blower dan portable sound system dapat dipenuhi oleh 4 panel sel surya fotovoltaik, pada cuaca cerah menghasilkan arus listrik 13,2 Amper, tegangan 19,2 Volt, sehingga tidak memerlukan genset atau listrik PLN. Bangunan panggung portable dan atap panggung tiup energi mandiri ini dapat menjadi prototip secara luas sebagai bangunan panggung yang cepat bangun energi mandiri. Penggunaan bahan tarpaulin dan
PVC sangat fleksibel dan kuat sehingga memudahkan proses pengangkutan, pemasangan dan pembongkaran kembali, dalam packaging yang simpel dan mudah digunakan.

\section{Saran}

Panggung portable dan atap panggung tiup dapat dibuat dalam skala besar sehingga memudahkan penyelenggara pameran produk kreatif UKM untuk memperbanyak frekuensi pameran.

Diperlukan sistem otomatisasi dalam pengaturan tekanan udara pada tabung tiup atap panggung pada blower pengisi udara. Selain itu diperlukan sun tracker untuk menyesuaikan sudut panel surya secara otomatis.

\section{UCAPAN TERIMA KASIH}

Ucapan Terima Kasih kami sampaikan kepada:

1. Kementerian RISTEKDIKTI yang telah memberikan dana penelitian;

2. LPPM Unmer Malang yang telah membantu regulasi dan administratif;

3. Prodi Arsitektur yang telah membantu peralatan laboratorium dan tempat diskusi;

4. Lab. Tekstil Universitas Islam Indonesia Yogyakarta yang telah membantu pengujian bahan tekstil.

5. Dosen, mahasiswa dan semua fihak yang telah berpartisipasi pada penelitian ini.

\section{REFERENSI}


Avallone, Eugene. 2006. Air-Inflated Fabric Structures: A Chapter For Marks'Standardhandbook For Mechanical Engineers. Reprint of a chapter in Marks'Standard Handbook for Mechanical Engineers, Eleventh Edition, New York: McGraw-Hill.

Budiyanto, Hery \& Rofieq, Mochammad. 2016.

Menumbubkembangkan Wirausaha Mahasiswa Dan Alumni Melalui Program Iptek Bagi Kewirausabaan Di Universitas Merdeka Malang. Jurnal ABDIMAS Universitas Merdeka Malang. Vol 1 no.1 Tahun 2016.

Budiyanto, H. Winansih, E. Setiawan, A. Setiawan, M. 2018. Portable Stage and Pneumatic Air Inflated Roof Structure with Independent Energy as a Means of Exhibition of SME Products. International Journal of Scientific Engineering and Research (IJSER). 2018 vol: 6 (9) pp: 48-51

Chassagnoux, Alain, et.al. 2002. Teaching of Morphology, International Journal of Space Structures, Vol.17 No. 2 \& 3, Multi Science Publishing Ltd., Brendwood (UK).

Manurung, A.H., 2006. Wirausaha: Bisnis UKM (Usaha

Kecil Menengab) . Jakarta: Penerbit Buku Kompas. Rofieq, Mochammad. Permatasari, Ditya. Farida,

Ditya Lailatul. 2018. Model Pendampingan

UMKM Bidang Kerajinan Menjadi Start-Up

Sukses Di Kota Malang. Jurnal ABDIMAS

Universitas Merdeka Malang. Vol 3 no.2 Tahun 2018.

Schodek, Daniel (1980) Structures. New Jersey: Prentice Hall. Inc

Sukawi, 2011.Struktur Membran dalam Bangunan Bentang Lebar. Jurnal MODUL Arsitektur Universitas
Diponegoro Semarang, vol. 11 no. 1 Januari 2011. ISSN: 0853-2877.

Widayana, Gede. 2012. Pemanfaatan Energi Surya. Jurnal Pendidikan Teknologi dan Kejuruan Universitas Pendidikan Ganesha. Vol.9 no.1 Tahun 2012. 